\title{
Study of prevalence and determinants associated with scabies in rural area of Bareilly
}

\author{
Dharmendra Kumar Gupta ${ }^{1}$, Rajendra Pal Singh², Atul Kumar Singh ${ }^{3}$, Ajay Kumar Agarwal ${ }^{4}$, Asheesh \\ Kumar $^{5}$, Urja Gava ${ }^{6}$
}

${ }^{1}$ Associate Professor, Department of Community Medicine, Shri Ram Murti Smarak Institute of Medical Sciences, Bareilly, Uttar Pradesh, India; ${ }^{2}$ Professor, Department of Community Medicine, Shri Ram Murti Smarak Institute of Medical Sciences, Bareilly, Uttar Pradesh, India; ${ }^{3}$ Professor \& Head, Department of Community Medicine, Shri Ram Murti Smarak Institute of Medical Sciences, Bareilly, Uttar Pradesh, India; ${ }^{4}$ Associate Professor, Department of Community Medicine, Rohilkhand Medical College, Bareilly, Uttar Pradesh, India; ${ }^{5}$ Medical Officer, Department of Community Medicine, Shri Ram Murti Smarak Institute of Medical Sciences, Bareilly, Uttar Pradesh, India; ${ }^{6}$ Intern, Department of Community Medicine, Shri Ram Murti Smarak Institute of Medical Sciences, Bareilly, Uttar Pradesh, India

\begin{tabular}{|l|l|l|l|l|l|l|l|}
\hline Abstract & Introduction & Methodology & Results & Conclusion & References & Citation & Tables/ Figures \\
\hline
\end{tabular}

\section{Corresponding Author}

Dr. Rajendra Pal Singh, Professor \& Medical Superintendent, Department of Community Medicine, Shri Ram Murti Smarak Institute of Medical Sciences, College in Abheypur Keshonpur, Bareilly, Uttar Pradesh - 243202

E Mail ID: rpsingh29@yahoo.co.in

\section{Citation}

Gupta DK, Singh RP, Singh AK, Agarwal AK, Kumar A, Gava U. Study of prevalence and determinants associated with scabies in rural area of Bareilly. Indian J Comm Health. 2021;33(1):169-174.

https://doi.org/10.47203/IJCH.2021.v33i01.023

Source of Funding: Nil Conflict of Interest: None declared

\section{Article Cycle}

Received: 02/12/2020; Revision: 13/02/2021; Accepted:15/03/2021; Published:31/03/2021

This work is licensed under a Creative Commons Attribution 4.0 International License.

\section{Abstract}

Background: Scabies, a contagious skin infestation by the mite Sarcoptes scabieii. It has no gender differences and infects all age group. This skin disease affects more than 300 million people per year worldwide, resulting in considerable morbidity, especially in resource-limited countries. Aims and Objectives: To find out prevalence and risk factor of scabies in rural population and to recommend measures for prevention and control of scabies. Material and Methods: A prospective cross sectional study was carried out over a period of 4 months from 1 Dec 2019 to 31 March 2020 in dermatology OPD at Rural health training centre (RHTC) of a medical college in Dhaura Tanda region of Uttar Pradesh. Total 310 patient including male and female of all age group were included in the study. Results: Majority of participants were females (58.1\%). The prevalence of scabies was $24.2 \%$ in population. The mean age at presentation was $28.819 \pm 10.198$ years. The most common affected age group was $12-24$ years (28.4\%). Conclusion: Scabies is a common skin disease in underdeveloped and developing countries. Poor living conditions such as inadequate housing, overcrowding, illiteracy, having animals in the house, unhygienic condition presence of family history and sharing clothes with others are important risk factors for transmission of scabies.

\section{Keywords}

Prevalence; Risk Factors; Rural; Sample Size; Scabies; Skin Disease 


\section{Introduction}

Scabies, one of the common public health problems, is a contagious skin infestation by the mite.(1) Sarcoptes scabiei or the itch mite is a parasitic mite (an arthropod) that burrow into skin, lays egg and causes scabies. Humans and Other mammals, such as wild and domesticated dogs and cats as well as ungulates, wild boars, bovid, wombats, koalas, and great apes are affected.(2) Scabies infection has no gender discrimination, it can infect both male and female of all age group commonly young and elderly population. It is a global health problem. Scabies prevalence was previously thought to be cyclical, but studies of long-term incidence suggest that epidemics and other observed fluctuations are multifactorial, being related to social and environmental changes such as wartime, overcrowding, and climatic changes. $(3,4,5,6)$ This skin disease affects more than $\mathbf{3 0 0}$ million people per year worldwide, resulting in considerable morbidity, especially in resource-limited countries. $(7,8)$ Whereas in developed nations the rates of infestation are similar across age ranges, the highest rates in developing countries are among preschool children to adolescents; rates significantly decrease in mid-adulthood, and increase in the elderly.(9) It is notable that particularly high prevalence figures have been reported in India, the South Pacific, and northern Australia. For example, in a study of young people in a rural Indian village, the prevalence of scabies was $70 \% .(10)$ The scabies mites usually spread by direct skin-to-skin contact with the infected person. It can also spread to other family members. Sometimes scabies can spread indirectly by sharing clothes, towels, or bedding used by infested individuals It has a significant impact in terms of cost of treatment, absence at work or school, and psychological repercussions. (11) Scabies has become a major public health problem, especially in limited resource settings. There is a scarcity of evidence regarding scabies prevalence and associated risk factors among schoolchildren in our study area.

\section{Aims \& Objectives}

1. To find out prevalence and risk factor of scabies in the rural area of Bareilly

2. To recommend measures for prevention and control of scabies.

\section{Material \& Methods}

It was a prospective cross-sectional study carried out over a period of 4 months from 1 Dec 2019 to 31 March 2020 after ethical approval from the institute on every Thursday in a dermatology OPD at rural health training centre (RHTC) of a medical college in Dhaura Tanda region Bhojipura block of Uttar Pradesh in India.

Sample size: Sample size ( $n$ ) was calculated by using the formula $(n)=4 P Q / L(5 \%$ of $p)$. Sample size was calculated by assuming the prevalence of scabies as $84 \%$ in a previous study (12) with $10 \%$ absolute error. By using the formula 4PO/L2 (5\% of p). Assuming $20 \%$ non-response-rate, the sample size was 258. Total 310 patients, both male and female of all the age group attending the skin OPD were included in the study during the study period.

Data collection: Socio demographic characteristics and associated risk factors were collected by trained health professionals by using structured questionnaire. The diagnosis was ascertained based on Mali clinical algorithm.(13) Operational definition: Scabies is defined as the presence of persistent pruritic rash with itching increasing at night which are notified at least at two specific body sites ( on the wrist, sides and web spaces of fingers, the axillae, peri-areolar, per umbilical, genitalia area, abdomen and buttocks) with or without history of pruritic in close entourage. (13)

\section{Type of house:}

Kaccha (Hut) - A mud build thatched (a roof covering of straw or reed) house

Semi-pacca (mixed) - Few rooms are brick built in a mud built house

Pacca (concrete) - Floor, roof and walls are made up of bricks.

\section{Education:}

Illiterate- A person age more than 7 years who can neither read nor write (no school education)

Literate- Age more than 7 years can read and write figures and his/her name in any language.

Overcrowding: Calculated by dividing the number of usual residents by number of rooms in the house. If it is more than 1.5, overcrowded, if equal or less not overcrowded.(14)

Inclusion criteria: All the patients attending the dermatology OPD at RHTC

Exclusion criteria: Pregnant mother, case of chronic skin disease and whose parents are not willing to participate. An informed consent was taken from all 
the patients. Data on demographic details, clinical findings, family history and past history was noted in predesigned performa.

Exclusion of observer bias: Throughout the study period, all patients were seen by same single third year PG resident in dermatology having adequate experience in identifying these lesions correctly. This eliminated the observer bias in study.

Statistical analysis: All the statistical analyses were performed using SPSS version 20 for Windows and the results reported as Chi-square Test.

\section{Results}

The most common affected age group was 1224 years $(28.4 \%)$. Majority of them were illiterate Muslim (53.2\%), female (58.1\%) living in joint family $(49.0 \%)$. Students $(28.4 \%$,$) were commonly affected$ followed by housewives $(25.5 \%)$ cases. (Table 1 )

Among 310 of the study participants 75 (24.2\%) scabies patients diagnosed at Derma OPD RHTC by dermatologist during the study period. females $(13.9 \%)$ were found more infected than male $32(10.3 \%)$ with scabies. Scabies was most prevalent in $12-24$ years $31(10.0 \%)$ age group. (Table2).

A number of epidemiological factors have been proposed that influence the distribution of scabies infestation in populations, including: age, gender, ethnicity, hygiene, and family history. Some other associated factors that influence scabies were poor housing and environmental condition like semipacca house (40.3\%), overcrowding (66.8\%), presence of livestock (52.6\%) and it also reported more cases in winter month (41.9\%) (Table 3)

According to the (Table 4), the most common topographical distribution site of scabies lesions were in finger webs $(85.3 \%)$, followed by localised in genitalia (69.3\%) hand(60\%), axilla(44.0\%), $\operatorname{arm}(38.7 \%)$,buttock(29.3\%) and foot(25.3\%), etc respectively.

\section{Discussion}

In this cross-sectional study our aim and objective was to find out prevalence and risk factor of scabies and to recommend measures for prevention and control of scabies in village of Bhojipura block. Scabies is common in lower socioeconomic groups, living in poor environmental and housing (semipacca/kaccha house with muddy floor, animal in house and presence of insect), in the current study, the total prevalence of scabies was $24.2 \%$ in a rural area of Rohilkhand region of Uttar Pradesh. In it, male and female prevalence were $10.3 \%$ and $13.9 \%$ respectively, most commonly in school children (10.0\%). This is higher than the prevalence of Scabies reported among school children in Ibadan, Nigeria, with a prevalence of $4.8 \%$.(15) On the other hand, higher prevalence rates of scabies were reported among Indian primary schoolchildren living in a slum of Kolkata with $39.42 \%$ prevalence.(16) Contact between children at school and between friends is likely to be important risk factors for disease transmission between children. Prevalence of scabies was more in female (13.9\%) in our study. This result was not in agreement with the results of other studies in countries like Nigeria (17) where the prevalence of scabies between males and females was equally. On the other hand, male predominance was observed in other Indian studies.(18) Scabies may be related to increased human personal contact and overcrowding living condition, sleeping on same bed as well as increased mite survival and fertility in cold weather. $(19,20)$ These are similar to our current study. Skin breaches from mite burrows and the excoriation from scratching, the itch often result in co-existing bacterial skin infection, up to $79 \%$ in some studies.(21) While in current study secondary bacterial skin infection were low (38.7\%). This study also revealed that sharing clothes (65.3\%) with other person and no daily bath (61.3\%) were associating factors of scabies. This finding was consistent with the study done in Doga-Tembi district, Tigray (22), Regarding the topographical distribution of scabies, more than $14 \%$ of the infested people had more than one type of lesion in various topographic sites, commonly on the abdomen, inguinal/thigh, interdigital space, hands, and wrists, confirming previous reports. $(23,24)$ In our study area, a climatedetermined behaviour in which people, particularly male children facing overcrowding and Close contact to each other facilitates transmission of scabies mite. This partly explained why lesions commonly occurred on the finger webs, genitalia, hand and axilla in this study. Interestingly, a recent interview study amongst general medical practitioners (GMPs) in Pakistan have demonstrated a diffuse "lack of knowledge regarding various aspects of scabies" and recommended an active intervention to improve their awareness, so that scabies will be identified and treated appropriately and valuable information will be provided to patients and communities. 


\section{Conclusion}

Scabies is a common skin disease in developing country. It causes various health problems like itching, distress and discomfort to children and families. Secondary bacterial infection is almost universal in this environment, with potentially serious consequences for the individual's health. Given the identified risk factors associated with scabies, steps should be taken to improve their hygiene practices and living conditions. Furthermore, dermatologists need to improve casefinding, and notification should be made mandatory, along with treatment of the affected individual and all those to whom they have been in contact with. Greater health awareness of scabies is needed among the public in general and programmes to achieve this should be implemented. Mass treatment of scabies either by oral Ivermectin or topical Permethrin is suggested. Action to control scabies in those countries where it has a significant impact on public health should now be a priority.

\section{Recommendation}

Health education to improve hygiene practices should be part of health care delivery practices in rural and low socioeconomic status urban population

\section{Limitation of the study}

Study has been at rural health training centre (RHTC) of a medical college covering a large village of a block of Uttar Pradesh in India, thus may not be a representative study for other parts of country. Since study was conducted on every Thursday in a dermatology OPD, it may have missed cases because of some social, personal or religious regions

\section{Relevance of the study}

The study has necessitated the importance of launching a vertical or horizontal national health program for prevention and control of scabies

\section{Authors Contribution}

DKG: Conceptualization, lead the project, performed data analysis and drafted the manuscript. RPS: supervision of study, analysis, manuscript revision. AKS, AKA, AK \& UG: involved in managing the project at site, data analysis and critically review of the manuscript. All authors read and approved the final manuscript.

\section{Acknowledgement}

We acknowledge participation of study participants, dedication of heath care workers at Rural Heath Training Center, and Medical officer of dermatology department for their devotion.

\section{References}

1. Gates, Robert H. Infectious disease secrets (2.ed.). Philadelphia: Elsevier, Hanley Belfus. 2003:355. ISBN 978-1-56053-543-0

2. Pence DB, Ueckermann E. Sarcoptic manage in wildlife. Rev Sci Tech. 2002;21(2):385-98. PMID: 11974622.[PubMed]

3. Andrews JR. Scabies in New Zealand. Int J Dermatol. 1979;18(7):545-52. doi: 10.1111/j.13654362.1979.tb01966.x. PMID: 387622.[PubMed]

4. Savin JA. Scabies in Edinburgh from 1815 to 2000. J R Soc Med. 2005;98(3):124-9. doi: 10.1258/jrsm.98.3.124. PMID: 15738560; PMCID: PMC1079418.[PubMed]

5. Christophersen J. The epidemiology of scabies in Denmark, 1900 to 1975. Arch Dermatol. 1978;114(5):747-50. PMID: 646397.[PubMed]

6. Burkhart CG, Burkhart CN, Burkhart KM. An epidemiologic and therapeutic reassessment of scabies. Cutis. 2000;65(4):233-40. PMID: 10795086.[PubMed]

7. Kouotou EA, Nansseu JR, Sieleunou I, Defo D, Bissek AC, Ndam EC. Features of human scabies in resource-limited settings: the Cameroon case. BMC Dermatol. 2015;15:12. doi: 10.1186/s12895-015-0031-0. PMID: 26201604; PMCID: PMC4512092.[PubMed].

8. Mbuagbaw J, Bissek C, Ozoh G, Etienne M. The epidemic of scabies in Yaounde. The internet Journal of Dermatology. 2006;4(2)

9. Burkhart $\mathrm{CG}$, Burkhart $\mathrm{CN}$, Burkhart $\mathrm{KM}$. An epidemiologic and therapeutic reassessment of scabies. Cutis. 2000;65(4):233-40. PMID: 10795086.[PubMed].

10. Nair BK, Joseph A, Kandamuthan M. Epidemic scabies. Indian J Med Res. 1977;65(4):513-8. PMID: 908603.[PubMed]

11. Abasiubong F, Akpan N, Ukpong D, Umanah I, Udoh S. Quality of life in patients with skin diseases in UYO, a community in south-south Nigeria. Adv Trop Med Pub Health Int. 2011;1(2):55-65

12. Tiwari J, Vikran K. Prevalence of scabies and Associated risk factors among patients attending general OPD of a community health centre in Panna district: a hospital based study 2015; 4(7):312-314.

13. Mahé A, Faye $O, N^{\prime}$ Diaye HT, Ly F, Konaré $H$, Kéita $S$, Traoré AK, Hay R. Definition of an algorithm for the management of common skin diseases at primary health care level in sub-Saharan Africa. Trans R Soc Trop Med Hyg. 2005;99(1):39-47. doi: 10.1016/j.trstmh.2004.03.008. PMID: 15550260. [PubMed]

14. Hegab DS, Kato AM, Kabbash IA, Dabish GM. Scabies among primary schoolchildren in Egypt: sociomedical environmental study in Kafr El-Sheikh administrative area. Clin Cosmet Investig Dermatol. 2015;8:105-11. doi: 
INDIAN JOURNAL OF COMMUNITY HEALTH / VOL 33 / ISSUE NO 01 / JAN-MAR2021 10.2147/CCID.S78287. PMID: 25759594; PMCID: PMC4345923.[PubMed].

15. Ogunbiyi AO, Owoaje E, Ndahi A. Prevalence of skin disorders in school children in Ibadan, Nigeria. Pediatr Dermatol. 2005;22(1):6-10. doi: 10.1111/j.15251470.2005.22101.x. PMID: 15660888.[PubMed]

16. Sarkar M. Personal hygiene among primary school children living in a slum of Kolkata, India. J Prev Med Hyg. 2013;54(3):153-8. PMID: 24783893; PMCID: PMC4718376.[PubMed]

17. Sambo MN, Idris SH, Umar AA, et al. Prevalence of Scabies Among School-aged Children in Katanga Nigeria. Ann. Rural Community in Kaduna state, Northwestern Nigerian Med. 2012; 6:26-29.

18. Sehgal VN, Rao TL, Rege VL, Vadiraj SN. Scabies: a study of incidence and a treatment method. Int J Dermatol. 1972;11(2):106-11. doi: 10.1111/j.13654362.1972.tb01733.x. PMID: 5024028.[PubMed]

19. Sokolova TV, Radchenko MI, Lange AB. Sezonnost' zabolevaemosti chesotki i polodovitost' chesotochnogo kleshcha Sarcoptes scabiei de Geer kak pokazatel' aktivnosti populiatsii vozbuditelia [The seasonality of scabies morbidity and the fertility of the itch mite [scabies in rural area...] | Gupta DK et al Sarcoptes scabiei de Geer as an index of the activity of a population of the causative agent]. Vestn Dermatol Venerol. 1989;(11):12-5. Russian. PMID: 2515675.[PubMed]

20. Hengge UR, Currie BJ, Jäger G, Lupi O, Schwartz RA. Scabies: a ubiquitous neglected skin disease. Lancet Infect Dis. 2006;6(12):769-79. doi: 10.1016/S14733099(06)70654-5. PMID: 17123897.[PubMed]

21. Romani L, Koroivueta J, Steer AC, Kama M, Kaldor JM, Wand $\mathrm{H}$, Hamid $M$, Whitfeld MJ. Scabies and impetigo prevalence and risk factors in Fiji: a national survey. PLoS Negl Trop Dis. 2015;9(3):e0003452. doi: 10.1371/journal.pntd.0003452. PMID: 25738499; PMCID: PMC4349858. [PubMed]

22. Hussien IA, Investigation of Scabies Outbreak South- East Zone, Tigray Regional State, Ethiopia. 2016.

23. Chosidow O. Clinical practices. Scabies. N Engl J Med. 2006;354(16):1718-27. doi: 10.1056/NEJMcp052784. PMID: 16625010.[PubMed]

24. Rathi SK, Rathi HS, Lakhani H, Hansotia MF. Awareness about scabies among general medical practitioners (GPs) of Karachi, Pakistan. J Pak Med Assoc. 2001;51(10):3702. PMID: 11768941.[PubMed].

\section{Tables}

\section{TABLE 1 DEMOGRAPHIC CHARACTERISTIC OF THE STUDY PARTICIPANTS}

\begin{tabular}{|l|l|l|}
\hline Study participants & Number & \\
\hline Ages(years) & 44 & 14.2 \\
\hline -12 & 88 & 28.4 \\
\hline $12-24$ & 51 & 16.5 \\
$24-36$ & 58 & 18.7 \\
$36-48$ & 69 & 22.3 \\
\hline $48-60$ \& above & & \\
\hline Sex & 130 & 41.9 \\
Male & 180 & 58.1 \\
\hline Female & & \\
\hline Religion & 165 & 53.2 \\
Muslim & 145 & 46.8 \\
\hline Hindu & & \\
\hline Types of family & 152 & 49 \\
\hline Joint & 77 & 24.8 \\
Nuclear & 81 & 26.1 \\
\hline Three generation & & \\
\hline Education & $184 / 126$ & $59.4 / 38.7$ \\
\hline Illiterate/literate & & \\
\hline Occupation & 88 & 28.4 \\
\hline Student & 79 & 25.5 \\
\hline Housewife & 59 & 19 \\
\hline Farmer & 49 & 15.8 \\
\hline Shopkeeper & 35 & 11.3 \\
\hline Unemployment & & \\
\hline Presence of scabies & 75 & 24.2 \\
\hline Yes & 235 & 75.8 \\
\hline No & 310 & 100 \\
\hline Total & & \\
\hline & & \\
\hline
\end{tabular}




\begin{tabular}{|c|c|c|}
\hline VARIABLES & SCABIES N (\%) & TOTAL N (\%) \\
\hline $\begin{array}{l}\text { Gender } \\
\text { Male } \\
\text { Female }\end{array}$ & $\begin{array}{l}32(10.3 \%) \\
43(13.9 \%)\end{array}$ & $\begin{array}{l}130(41.9 \%) \\
180(58.1 \%)\end{array}$ \\
\hline $\begin{array}{l}\text { Age } \\
0-12 \\
12-24 \\
24-36 \\
36-48 \\
48-60 \text { and above }\end{array}$ & $\begin{array}{l}11(3.5 \%) \\
31(10.0 \%) \\
9(2.9 \%) \\
8(2.6 \%) \\
16(5.2 \%)\end{array}$ & $\begin{array}{l}44(14.2 \%) \\
88(28.4 \%) \\
51(16.5 \%) \\
58(18.7 \%) \\
69(22.3 \%)\end{array}$ \\
\hline Total & 75 (24.2\%) & 310 (100\%) \\
\hline
\end{tabular}

\section{TABLE 3 DISTRIBUTIONS OF FACTORS RESPONSIBLE FOR SCABIES (75)}

\begin{tabular}{|l|l|l|}
\hline VARIABLES & FREQUENCY & PERCENTAGE \\
\hline Housing : Kaccha/Semipacca/Pacca & $27 / 34 / 14$ & $36 \% / 45.3 \% / 18.7 \%$ \\
\hline Muddy floor: Yes / no & $44 / 31$ & $58.7 \% / 41.3 \%$ \\
\hline Hygiene : Good /Average / Poor & $9 / 25 / 41$ & $12 \% / 33.4 \% / 54.6 \%$ \\
\hline Economy: High / medium /low & $7 / 38 / 30$ & $9.3 \% / 50.7 \% / 40.0 \%$ \\
\hline Education of mother : Illiterate / Literate & $43 / 32$ & $57.3 \% / 42.7 \%$ \\
\hline Education of father: Illiterate / Literate & $39 / 36$ & $52.0 \% / 48.0 \%$ \\
\hline Family history: Present / Absent & $63 / 12$ & $84 \% / 16 \%$ \\
\hline Overcrowding: (Yes / No) & $51 / 24$ & $68 \% / 32 \%$ \\
\hline Bathing daily: (Yes / No) & $29 / 46$ & $38.7 \% / 61.3 \%$ \\
\hline Sharing cloth: (Yes / No) & $49 / 26$ & $65.3 \% / 34.7 \%$ \\
\hline Sleeping on common bed: (Yes / No) & $55 / 20$ & $73.3 \% / 26.7 \%$ \\
\hline Contact with scabies patients: (Yes / No) & $62 / 13$ & $82.7 \% / 17.3 \%$ \\
\hline Climate: Summer / Autumn/Winter & $18 / 24 / 33$ & $24 \% / 32 \% / 44 \%$ \\
\hline Livestock : (Yes / No) & $44 / 31$ & $58.7 \% / 41.3 \%$ \\
\hline Insects: Present / Absent & $66 / 09$ & $88 \% / 12 \%$ \\
\hline Secondary infection: Yes / No & $29 / 46$ & $38.7 \% / 61.3 \%$ \\
\hline
\end{tabular}

\section{TABLE 4 TOPOGRAPHICAL DISTRIBUTION OF SCABIES ACCORDING TO THE SITE OF INFESTATION.}

\begin{tabular}{|l|l|l|}
\hline SITE OF INFESTATION & NUMBER & \multicolumn{1}{c|}{ PERCENTAGE } \\
\hline In finger webs & 64 & $85.3 \%$ \\
\hline Genitals & 52 & $69.3 \%$ \\
\hline Hand & 45 & $60 \%$ \\
\hline Axilla & 33 & $44 \%$ \\
\hline Arm & 29 & $38.7 \%$ \\
\hline Buttock & 22 & $29.3 \%$ \\
\hline Abdomen & 22 & $29.3 \%$ \\
\hline Foot & 19 & $25.3 \%$ \\
\hline Generalized & 17 & $22.7 \%$ \\
\hline Flexor of wrist & 13 & $17.3 \%$ \\
\hline Elbow & 13 & $17.3 \%$ \\
\hline Armpit & 9 & $12 \%$ \\
\hline Penis & 9 & $12 \%$ \\
\hline Nipple & 5 & $6.7 \%$ \\
\hline
\end{tabular}

